\title{
BASIC IDEAS FOR DETERMINING DEATH CRIMINAL THREATS IN LAW NUMBER 35 OF 2009 ON NARCOTICS
}

\author{
Faissal Malik \\ Fakultas Hukum \\ Universitas Khairun Ternate \\ Email : faissalmalik10@gmail.com
}

\begin{abstract}
The basic idea of using the threat of capital punishment against perpetrators of "producers and dealers" regulated by Law Number 35 of 2009 concerning Narcotics as a policy to combat narcotics crime is based on several reasons, including: First, narcotics crimes committed by perpetrators of "producers and distributors "Organized and systematic patterns, because they are carried out with a very sophisticated modus operandi and have networks to circulate and trade for purely economic interests, so it is not easy to uncover and prove it. Second, the circulation and abuse of illicit drug trafficking by perpetrators of "producers and distributors" is a threat that sooner or later gives a serious impact because it destroys young generation, destroys the nation and the state that is not less powerful than criminal acts of terrorism and corruption, due to the fact that arising from narcotics abuse has caused victims of HIV / AIDS and hepatitis, even death among the very young generation. So that the Government of the Republic of Indonesia is of the view that the actions of the perpetrators of "producers and distributors" in producing and distributing narcotics are crimes against humanity, because their actions can destroy humanity slowly but surely.
\end{abstract}

Keywords: Narcotics, criminal policy, corruption, capital punishment

\begin{abstract}
Abstrak
Ide dasar penggunaan ancaman pidana mati terhadap pelaku "produsen dan pengedar" yang diatur Undang-Undang Nomor 35 Tahun 2009 tentang Narkotika sebagai kebijakan penanggulangan tindak pidana narkotika didasarkan pada beberapa alasan, diantaranya: Pertama, tindak pidana narkotika yang dilakukan oleh pelaku "produsen dan pengedar "pola terorganisasi dan sistematis, karena dilakukan dengan modus operandi yang sangat canggih dan memiliki jejaring untuk mengedarkan dan memperdagangkan untuk kepentingan ekonomi semata, sehingga tidak mudah untuk mengungkap dan membuktikannya. Kedua, peredaran dan penyalahgunaan peredaran gelap narkotika oleh pelaku "produsen dan pengedar" merupakan ancaman yang cepat atau lambat member dampak yang serius karena menghancurkan genarasi muda, penghancur bangsa dan negara yang tak kalah dahsyatnya dengan tindak pidana terorisme dan korupsi, karena fakta menunjukkan bahwa akibat yang ditimbulkan dari penyalahgunaan narkotika telah menimbulkan korban berupa penyakit HIV/AIDS dan hepatitis bahkan
\end{abstract}


kematian dikalangan generasi muda yang sangat tinggi. Sehingga Pemerintah Republik Indonesia berpandangan bahwa tindakan pelaku "produsen dan pengedar" dalam memproduksi dan mengedarkan narkotika merupakan kejahatan kemanusiaan, karena tindakannya dapat memusnakan umat manusia secara perlahan tapi pasti.

\section{Kata kunci : Narkotika, kebijakan pidana, korupsi, pidana mati}

\section{Introduction}

The development of dark circulation and abuse of narcotics and other addictive substances has become an important topic. This has become a serious problem and has reached a state of concern because it occurs within the national scope and has crossed national boundaries when viewed from the convergence and technology used. Illegal circulation and abuse of narcotics has extended beyond the boundaries of social strata, age, gender. Urban is no longer a priority of dealers but has penetrated to the countryside and exceeded national borders which consequently is very detrimental to individuals, communities and the state. ${ }^{1}$ This situation puts the illicit circulation and abuse of narcotics into the common enemy of nations in the world because the impact is very damaging to humanity, especially the younger generation. That is what causes a joint agreement from countries in the world to fight narcotics and other addictive substances that are circulated illegally.

Several Asian regions are identified as one of the main sources of the biggest narcotics producers in the world, such as the golden crescent region which covers the border regions of Afghanistan and Pakistan, the golden traiangle region which covers the border regions of Myanmar, Laos and Thailand. perpetrators (producers and distributors) of narcotics crimes. ${ }^{2}$ This is done because the illegal circulation of narcotics is a business land that is very economically profitable. Producers, dealers, and couriers enjoy enormous financial benefits in the not too distant future, while users or users are promised an infinite pleasure after using narcotics.

From the description above, if it is connected with Indonesia, it is undeniable that Indonesia is a potential narcotics market and other addictive substances due to supply and demand activities. In addition, many parties argue that Indonesia is also a black market for the illicit circulation of narcotics run by a network of local and international narcotics syndicates. The entrance of narcotics to Indonesia is very open, both by land, sea and air. Recruitment to look for narcotics is very easy and inexpensive, so it is not surprising if there are many users found in Indonesia and drug addicts. ${ }^{3}$ It is predicted that the number of people involved in the illicit

1 Syamsul Hidayat \& Hasan Asy”ari, 2013, “Kontroversi Penerapan Pidana Mati Terhadap Tindak Pidana Narkoba”, Dalam Jurnal IUS Kajian Hukum dan Keadilan, Vol I Nomor 3 Desember hlm. 500-501.

2 Wendra Hartanto, 2017, "Penegakan Hukum Terhadap Kejahatan Narkotika dan Obat-Obat Terlarang Dalam Era Perdagangan Bebas Internasional Yang Berdampak Pada Keamana dan Kedaulatan Negara" Jurnal Legislasi Indonesia, ISSN 0216-1338, hlm, 11

3 Dikemukakan oleh Santoso, 2013, Selaku Kepala Badan Narkotika Provinsi Maluku (BNP), Sebagaimana dikutip di Media Indonesia, Com, Indonesia "Surga Pengedar Narkoba Internasional” 26 Januari. 
trafficking of narcotics and narcotics abuse will increase from year to year, if there is no effort to prevent, overcome and eradicate seriously and consistently.

The increasing illicit circulation of narcotics and narcotics abuse can be seen through BNN data which shows that the number of narcotics circulating during 2004 was 567.2 tons per year for cannabis, while for heroin / putau there were 20.4 tons per year. If 1 (one) package of heroin / putau is absorbed by the market of addicts in Indonesia. This condition at least confirms that Indonesia is a lucrative market for syndicates of domestic and international narcotics producers and distributors, who provide huge amounts of money with very large profits to the syndicate. $^{4}$

Meanwhile, the 2008 data, it can be stated that the number of narcotics abusers has reached $1.5 \%$ of the total population of Indonesia or around 3, 1 million to 3, 6 million people. Of the number of abusers, $26 \%$ tried to use, $27 \%$ regularly used $40 \%$ of non-injecting addicts and $7 \%$ were injecting addicts. Narcotics abuse in groups not students $(40 \%)$. Whereas according to male sex $(88 \%)$ is far greater than female $(12 \%)$. The estimated loss of economic costs due to narcotics crime in 2008 was higher by around $37 \%$ compared to 2004, with a total loss of around Rp. 32.4 trillion (2008) consisting of Rp. 26.5 trillion individual (private) losses and Rp. 5.9 trillion is social costs. The private costs are mostly (58\%) for the cost of consuming narcotics, while the social costs are mostly (60\%) intended for loss of costs due to premature dealth. The projection of the University of Indonesia's Research Institute in collaboration with the National Narcotics Agency (BNN) shows that economic losses due to narcotics abuse have increased from Rp. 32.4 trillion in 2008 to Rp. 57 trillion in 2013. ${ }^{5}$ University of Indonesia (UI) Research Data in collaboration with the National Narcotics Agency (BNN) mentioned above shows that the actions of producers and dealers in producing and distributing narcotics illegally on their networks to be traded on users or users continue to increase. This condition certainly threatens and endangers the lives of people, nations and countries.

The description above, at least illustrates the situation of Indonesia entering the narcotics emergency. Every line of human life for narcotics users and dealers is there. Users certainly need to be rehabilitated, as well as socialization needs to be done to prevent potential users. However, producers and distributors who produce and distribute narcotics certainly must be punished severely. The death penalty is not inappropriate for them. Many victims and victims have dependence on narcotics abuse. Not to mention those affected by narcotics-related diseases. Also, the number of crimes related to circulation and use continues to increase. Circulation of narcotics in Indonesia has reached the point of transforming Indonesia from a transit country into a destination country. Even in Indonesia, many parties produce narcotics. ${ }^{6}$

\footnotetext{
$4 \quad$ Hasil Penelitian Universitas Indonesia (UI) Bekerjasama dengan Badan Narkotika Nasional (BNN) pada tahun 2008, Sebagaimana dikutip dalam Achmad Rivai, 2014, Narkoba Di Balik Tembok Penjara, Yogyakarta, Aswaja Pressindo, hlm, 26-27

6 Hikmahanto Juwana, 2015, “Narkoba dan Hukuman Mati” Kompas, Senin 19 Januari
} 
Several Asian regions are identified as one of the main sources of the biggest narcotics producers in the world, such as the golden crescent region which covers the border regions of Afghanistan and Pakistan, the golden traiangle region which covers the border regions of Myanmar, Laos and Thailand. perpetrators (producers and distributors) of narcotics crimes. ${ }^{7}$ This is done because the illegal circulation of narcotics is a business land that is very economically profitable. Producers, dealers, and couriers enjoy enormous financial benefits in the not too distant future, while users or users are promised an infinite pleasure after using narcotics.

From the description above, if it is connected with Indonesia, it is undeniable that Indonesia is a potential narcotics market and other addictive substances due to supply and demand activities. In addition, many parties argue that Indonesia is also a black market for the illicit circulation of narcotics run by a network of local and international narcotics syndicates. The entrance of narcotics to Indonesia is very open, both by land, sea and air. Recruitment to look for narcotics is very easy and inexpensive, so it is not surprising if there are many users found in Indonesia and drug addicts. ${ }^{8}$ It is predicted that the number of people involved in the illicit trafficking of narcotics and narcotics abuse will increase from year to year, if there is no effort to prevent, overcome and eradicate seriously and consistently.

The increasing illicit circulation of narcotics and narcotics abuse can be seen through BNN data which shows that the number of narcotics circulating during 2004 was 567.2 tons per year for cannabis, while for heroin / putau there were 20.4 tons per year. If 1 (one) package of heroin / putau is absorbed by the market of addicts in Indonesia. This condition at least confirms that Indonesia is a lucrative market for syndicates of domestic and international narcotics producers and distributors, who provide huge amounts of money with very large profits to the syndicate. ${ }^{9}$

Meanwhile, the 2008 data, it can be stated that the number of narcotics abusers has reached $1.5 \%$ of the total population of Indonesia or around 3, 1 million to 3, 6 million people. Of the number of abusers, $26 \%$ tried to use, $27 \%$ regularly used $40 \%$ of non-injecting addicts and $7 \%$ were injecting addicts. Narcotics abuse in groups not students (40\%). Whereas according to male sex $(88 \%)$ is far greater than female $(12 \%)$. The estimated loss of economic costs due to narcotics crime in 2008 was higher by around $37 \%$ compared to 2004, with a total loss of around Rp. 32.4 trillion (2008) consisting of Rp. 26.5 trillion individual (private) losses and Rp. 5.9 trillion is social costs. The private costs are mostly (58\%) for the cost of consuming narcotics, while the social costs are mostly (60\%) intended for loss of costs due to premature dealth. The projection of the University of Indonesia's Research Institute in collaboration with the National Narcotics Agency (BNN)

\footnotetext{
7 Wendra Hartanto, 2017, “Penegakan Hukum Terhadap Kejahatan Narkotika dan Obat-Obat Terlarang Dalam Era Perdagangan Bebas Internasional Yang Berdampak Pada Keamana dan Kedaulatan Negara” Jurnal Legislasi Indonesia, ISSN 0216-1338, hlm, 11

8 Dikemukakan oleh Santoso, 2013, Selaku Kepala Badan Narkotika Provinsi Maluku (BNP), Sebagaimana dikutip di Media Indonesia, Com, Indonesia "Surga Pengedar Narkoba Internasional” 26 Januari.

9 Hasil Penelitian Universitas Indonesia (UI) Bekerjasama dengan Badan Narkotika Nasional (BNN) pada tahun 2008, Sebagaimana dikutip dalam Achmad Rivai, 2014, Narkoba Di Balik Tembok Penjara, Yogyakarta, Aswaja Pressindo, hlm, 26-27
} 
shows that economic losses due to narcotics abuse have increased from Rp. 32.4 trillion in 2008 to Rp. 57 trillion in $2013 .{ }^{10}$ University of Indonesia (UI) Research Data in collaboration with the National Narcotics Agency (BNN) mentioned above shows that the actions of producers and dealers in producing and distributing narcotics illegally on their networks to be traded on users or users continue to increase. This condition certainly threatens and endangers the lives of people, nations and countries.

The description above, at least illustrates the situation of Indonesia entering the narcotics emergency. Every line of human life for narcotics users and dealers is there. Users certainly need to be rehabilitated, as well as socialization needs to be done to prevent potential users. However, producers and distributors who produce and distribute narcotics certainly must be punished severely. The death penalty is not inappropriate for them. Many victims and victims have dependence on narcotics abuse. Not to mention those affected by narcotics-related diseases. Also, the number of crimes related to circulation and use continues to increase. Circulation of narcotics in Indonesia has reached the point of transforming Indonesia from a transit country into a destination country. Even in Indonesia, many parties produce narcotics. $^{11}$

\section{Literature Review \\ 2.1 Definition of Narcotics}

Various limitations of the definition of narcotics in the literal sense and expert opinion, at least illustrate the complexity because narcotics issues have a broad dimension, both from the medical, psychiatric, mental and psychosocial aspects. ${ }^{12}$ Nevertheless, in order to obtain a description of the definition and definition of narcotics, it is necessary to put forward some definitions and definitions of narcotics both literally and according to experts, so as to facilitate understanding the definition of narcotics.

Etymologically narcotics comes from English "narcose" or "narcosis" which means to sleep and anesthetize. ${ }^{13}$ Narcotics comes from Greek, which is "narcotics" which means anesthetized so that it doesn't feel anything. In terminology, in the

\footnotetext{
Ibid

Hikmahanto Juwana, 2015, “Narkoba dan Hukuman Mati” Kompas, Senin 19 Januari Narkotika dalam arti medis diartikan sebagai zat atau obat yang digunakan untuk penekan rasa sakit dikulit, untuk pembedahan mata, hidung dan tenggorokan. Narkotika dalam arti psikiatri adalah zat atau obat yang mempengaruhi aspek kesehatan jiwa serta pengaruhnya terhadap fungsi-fungsi tubuh manusia. Narkotika dalam arti kesehatan jiwa adalah zat atau obat yang mempengaruhi suatu kondisi sehat, emosional, psikologis, dan hubungan interpersonal yang memuaskan, perilaku yang efektif dan kestabilan emosi. Sedangkan narkotika dalam arti psikososial adalah zat atau obat yang berpengaruh terhadap perkembangan emosi, motivasi dan perkembangan pribadi manusia, Diakses dari http://dedyarta Wordpress.com/2015/02/15/manfaat-narkotika dan psikotropika dalam bidang kesehatan, pada tanggal, 20 April 2019

13 Jhon M. Elthols dan Hasan Sadili, 1996, Kamus Inggris Indonesia, Jakarta, Gramedia Cet.XXIII, hlm, 390.
} 
Large Indonesian Language Dictionary (KBBI) means narcotics is a drug that can calm nerves, eliminate pain, cause a feeling of drowsiness, or stimulate. ${ }^{14}$

Different from the meaning in the literal sense, Smith Kline and French Clinical as quoted by Mardani, defines narcotics as follows:

Narcotic are drugs which produce incencibility or stuper due to their depressant effect on the central system. Included in this definition tire opium, opium derivatives (morphine, codeine, heroin) and synthetic opiates (meperidei, methadone). ${ }^{15}$

Menurut Wiliam Benton:

Narcotic is general term for substance that produsce lethargi or super or the relief of pain. ${ }^{16}$

According to Soedjono Dirdjosisworo:

Narcotics are ingredients which mainly have the effect of anesthetic work or can reduce consciousness. ${ }^{17}$

The definition and opinion of experts on the definition of narcotics as stated above shows that narcotics are substances or substances that can function as drugs that can affect consciousness, but if misused it can damage the physical (such as addiction) and mentally (loss of consciousness, behavior, encouragement wishes) of the wearer, both natural material and synthesis (results of laboratory processing).

The definition of narcotics, which is regulated in Article 1 Paragraph (1) of Law Number 35 of 2009 concerning Narcotics, is substances or drugs derived from plants or plants that are both synthetic and semisynthetic which can cause a decrease or change in consciousness, loss of taste, reduce to eliminate pain, and can cause dependence which is differentiated into groups as attached to the law.

\subsection{Regulation of Narcotics Criminal Law in Indonesia}

The problem of abuse of narcotics and illegal drugs (narcotics) in the past three decades has not only become a national and asean regional problem but also an international problem. Efforts to overcome the problem of narcotics abuse in the country must be synergized and integrated with narcotics problem management policies through regional and international cooperation. ${ }^{18}$

In Indonesia, arrangements have been made regarding efforts to address the problem of narcotics abuse. This is as contained in several laws and regulations

\footnotetext{
14 Anton M. Moelyono, 1988, Kamus Besar Bahasa Indonesia, Jakarta, Balai Pustaka, hlm .609 .

15 Mardani, 2008, Bunga Rampai Hukum Aktual, Jakarta, Ghalia Indonesia, hlm 15.

Ibid

Soedjono Dirdjosisworo, 1997, Patologi Sosial, Bandung, Alumni, hlm.78.

I Nyoman Nurjaya, 2005, "Penanggulangan Kejahatan Narkotika Dalam Perspektif Sosiologi Hukum”, Malang, Legality; Jurnal Ilmiah Hukum, Fakultas Hukum Universitas Muhammadiyah , hlm. 1.
} 
specifically regulating narcotics crimes, or in other words special criminal laws, ${ }^{19}$ among others are :

a. Republic of Indonesia Law Number 9 Year 1976 concerning Narcotics (Republic of Indonesia State Gazette Year 1976 No. 36, Republic of Indonesia National TLN No. 3086)

Initially the global policy on combating narcotics crimes was outlined in The United Nation's Single Convention on Narcotic Drugs 1961. In this convention it was basically intended to:

1. Creating international conventions that can be accepted by countries in the world and can oversee regulations regarding international supervision of narcotics abuse which are separate in 8 material agreements;

2. Improve ways to supervise the circulation of narcotics and limit their use, especially for the benefit of medical treatment and development;

3. Ensure international cooperation in the supervision of drug trafficking to achieve the above objectives.

In addition, in the 1961 Single Narcotics Convention stipulated in New York, in Article 1 the definitions for the purposes of the convention included: Cannabis (marijuana), Cannabis plant (Cannabis plant), Cannabis resin (cannabis seeds), Coca bush (coca plant), Coca leaf (coca leaf), Medical opium (drug opium), Opium, Opium poppy (papaver plant), Poppy straw (straw papaver plant).$^{20}$

Indonesia as one of the countries that co-signed the convention, then ratified it through Law No. 8 of 1976 concerning Ratification of the Single Convention on Narcotics 1961 along with the Protocol amending it. Furthermore, the legal instrument which was later created by the government to combat narcotics crimes in the country was Law No. 9 of 1976 concerning Narcotics.

Law No. 9 of 1976 concerning Narcotics is a substitute for the Act on Drugs inherited from the Dutch colonial government, namely Verdoovende Middelen Ordonnantie 1927 (Stbl.1927 No. 278 jo No. 536) dated May 12, 1927. This ordinance consists of 29 articles which at Basically, it has regulated the problem of drug use and circulation. This ordinance regulates how narcotics exports and imports can be carried out. Besides this ordinance has also provided restrictions on the use of several types of narcotics. In the event of a violation, this ordinance has also been equipped with criminal rules. ${ }^{21}$

Aside from being a substitute for the Drugs Act on the inheritance of the Dutch colonial government, Law No. 9 of 1976 was issued with consideration: That narcotics is a drug that is needed in the field of medicine and science and narcotics can also create a very harmful dependence on used without careful limitation and supervision. Making, storing, distributing, and using narcotics without strict limitation and supervision and contrary to applicable regulations constitutes a crime that is very detrimental to individuals, the community and is a great danger to human life and state life in the political, security, economic, social, cultural fields

Sudarto, Op. Cit., hlm. 64.

Sudarto, Op. Cit., hlm. 38.

Soedjono Dirjosisworo,1990, Hukum Narkotika Indonesia, Cet. 2, Bandung : Citra Aditya Bakti, hlm. 10. 
and the national resilience of the Indonesian people who are developing. Rules for the provision and use of narcotics for medical and / or scientific purposes as well as for preventing and overcoming the dangers that can be caused by side effects of narcotics use and abuse and rehabilitation of new narcotics addicts. ${ }^{22}$

In the criminal provisions contained in Law Number 9 Year 1976 regulating the threat of capital punishment, life sentence, maximum 20 (twenty) years imprisonment and accumulated with criminal penalties ranging from Rp. 1,000.00 (one million rupiah) to Rp. 50,000,000 (fifty million rupiah). ${ }^{23}$

b. Republic of Indonesia Law Number 22 Year 1997 concerning Narcotics (Republic of Indonesia Year 1997 No. 67, Indonesian National TLN No. 3698)

Indonesia has ratified the 1998 United Nations Convention on the Eradication of Illicit Narcotics and Psychotropic Circulation (United Nations Convention Against Illicit Traffic in Narcotics Drugs and Psycotropic Substance, 1988) with Act No. 7 of 1997. According to this convention, the state who have ratified the obligation to fight illicit drug trafficking and provide severe sanctions to the perpetrators. ${ }^{24}$

Law No. 22 of 1997 was then issued on September 1, 1997 to replace Law Number 9 of 1976, while also considering that narcotics crimes were transnational in nature using high modus operandi and sophisticated technology, while regulations the existing legislation is not in accordance with the development of the situation and the conditions that develop to overcome the crime. ${ }^{25}$

In Law Number 35 of 2009, there has also been a minimal criminal threat, in which the minimum criminal threat provisions in this law constitute an improvement from the provisions that have been previously in Law Number 22 of 1997. In other words, when invited Previously, namely Law Number 22 of 1997, the regulation of criminal threats is minimally only found in a number of articles in the criminal provisions, then in Law Number 35 of 2009, a minimum criminal threat is found in all Articles with criminal provisions. In addition, the minimum criminal threat in this law is not only intended for punishment and applied in certain circumstances, such as if the criminal act is preceded by a conspiracy agreement or if it is organized in an organized manner, but also applies to the principal actions committed by everyone or every individual who acts as the perpetrator of a narcotics crime.

In an effort to protect the public from the dangers of narcotics abuse preventing and eradicating illicit drug trafficking, this law also regulates narcotics

22 UU No. 9 Tahun 1976 memuat 4 point pertimbangan, yang merupakan produk hukum Bangsa Indonesia, dalam mengatur cara penyediaan dan penggunaan narkotika serta mencegah dan menanggulangi bahaya-bahaya yang dapat ditimbulkan oleh akibat sampingan dari penggunaan dan penyalahgunaan narkotika.

23 Lihat Ketentuan Pidana yang terdapat dalam Pasal 36 hingga Pasal 53 Undang-Undang RI No. 9 Tahun 1976 tentang Narkotika, LN RI Tahun 1976 No. 36, TLN RI No. 3086

24 OC. Kaligis dan Associates,2007, Narkoba dan Peradilannya di Indonesia Reformasi Hukum Pidana Melalui Perundangan dan Peradilan, Cet. 2, Bandung : Alumni, hlm. 270.

25 Konsideran UU No. 22 Tahun 1997 tentang Narkotika, LN RI Tahun 1997 No. 67, TLN RI No. 3698. 
precursors, because narcotics precursors are substances or beginner substances or chemicals that can be used in the manufacture of narcotics. In addition, it also regulates criminal sanctions for the abuse of narcotics precursors for the manufacture of narcotics.

In order to create a deterrent effect on the perpetrators of abuse and illicit trafficking in narcotics and narcotics precursors, this law also regulates the imposition of criminal sanctions, both in the form of minimum criminal penalties, 20 (twenty) years imprisonment, life imprisonment, and capital punishment. The criminal charges are carried out based on the class, type, size and number of Narcotics.

\section{Discussion and Results of Research}

The regulation of criminal provisions in Law No. 35 of 2009 concerning Narcotics is regulated in Chapter XV of Articles 111 to 148, with the stipulation of criminal sanctions in the form of special minimum, general maximum and special criminal penalties. The regulation of sanctions is very different from the formulation of the Criminal Code which is the parent of criminal legislation in Indonesia, the criminal formula used is the general minimum, both for imprisonment and confinement for 1 (one) day (Article 12 Paragraph (2) and Article 18 Paragraph ( 1) Criminal Code), as well as special general and maximum maximum. That is, there are different rules, especially regarding "special minimum criminal", because the Criminal Code as a parent system does not recognize a specific minimum in terms of punishment. Specific minimum criminal sanctions against narcotics abuse by producers, dealers, are regulated in a special minimum form of criminal, namely 20 (twenty) years imprisonment, life imprisonment, and capital punishment. The criminal threat is carried out based on the class, type, size and number of narcotics.

Determination of the threat of capital punishment against perpetrators with qualifications as producers and distributors as stipulated in Article 113 Paragraph (2) which reads: In the case of acts of producing, importing, exporting or distributing Narcotics Group I as referred to in paragraph (1) in the form of plants exceeding 1 (one) kilogram or more than 5 (five) tree trunks or in the form of nonplant weight exceeding 5 (five) grams, the offender shall be punished with capital punishment, life imprisonment, or imprisonment for a minimum of 5 (five) years and maximum 20 (twenty) years and maximum fine penalty as referred to in paragraph (1) plus 1/3 (one third). Article 114 Paragraph (2) reads: In the case of acts of conduct offering for sale, selling, buying, broking in buying and selling, exchanging, surrendering, or receiving Narcotics Group I as referred to in paragraph (1) in the form of plants exceeding 1 (one) kilogram or more than 5 (five) tree trunks or in the form of non-plants weighing 5 (five) grams, the perpetrator is punished with capital punishment, imprisonment for life, or imprisonment for a minimum of 6 ( six) years and maximum 20 ( twenty) years and the maximum criminal penalty as referred to in paragraph (1) plus $1 / 3$ (one third).

Article 116 Paragraph (2) reads: In the case of the use of narcotics against other people or the provision of Narcotics Group I for use by other people as 
referred to in paragraph (1) causing other people to die or parmanen disability, the perpetrator is sentenced to death, life imprisonment, or imprisonment of a maximum of 5 (five) years and a maximum of 20 (twenty) years and a maximum criminal penalty as referred to in paragraph (1) plus $1 / 3$ (one third). Article 118 Paragraph (2) reads: In the case of the act of producing, importing, exporting, or distributing Narcotics Group II as referred to in paragraph (1) the weight exceeds 5 (five) grams, the offender is punishable by death, life imprisonment, or criminal imprisonment of at least 5 (five) years and a maximum of 20 years (two pulu) years and a maximum criminal penalty as referred to in paragraph (1) plus $1 / 3$ (one third). Article 119 Paragraph (2) reads: In the case of acts offering to sell, sell, buy, receive, mediate in buying and selling, exchange, mediate or submit Narcotics Group II as referred to in paragraph (1) the weight exceeds 5 (five) grams, the perpetrator is punished with capital punishment, life imprisonment, or imprisonment for a minimum of 5 (five) years and a maximum of 20 (twenty) years and a maximum fine penalty as referred to in paragraph (1) plus $1 / 3$ (one third).

Article 121 Paragraph (2) reads: In the case of Narcotics use against other people or the provision of Narcotics Group II for use by other people as referred to in paragraph (1) causing other people to die or parmanen disability, the offender is sentenced to death, life imprisonment, or imprisonment for a minimum of 5 (five) years and a maximum of 20 (twenty) years and a maximum criminal fine as referred to in paragraph (1) plus 1/3 (one third); and Article 133 Paragraph (1) reads: Everyone who orders, gives or promises something, provides opportunities, encourages, provides convenience, forces with threats, forces violence, deceives, or persuades children who are not old enough to act criminal as referred to in Article 111, Article 112, Article 113, Article 114, Article 115, Article 116, Article 117, Article 119, Article 120, Article 121, Article 122, Article 123, Article 124, Article 125, Article 126, and Article 129 shall be punished with capital punishment or life imprisonment or imprisonment for a minimum of 5 (five) years and a maximum of 20 (twenty) years and a fine of at least Rp. 2,000,000,000.00 (two billion rupiahs) and a maximum of Rp.20,000,000,000.00 (twenty billion rupiah) Law Number 35 of 2009 concerning Narcotics which is the focus of the study in writing this dissertation. This research is important to be able to find out what is the philosophical basis for the determination of the threat of capital punishment against producers and dealers in Law No. 35 of 2009 concerning Narcotics amid an endless debate about whether or not the policy of regulating the death penalty in the criminal law system is important Indonesia.

Regarding the regulation of the threat of capital punishment in Law Number 35 of 2009 concerning Narcotics, starting from the idea to renew Law Number 22 Year 1997 concerning Narcotics which is getting stronger. This was indicated by the MPR giving a recommendation to the President to renew Law No. 22 of 1997 concerning Narcotics through MPR Decree No.VI/MPR/2002 concerning Recommendations on the Report of the Implementation of the People's Consultative Assembly Decision by the President, DPA, DPR, BPK, and MA. In this MPR TAP, the MPR looked at narcotics issues on three sides, namely those related to morality in reducing morality, increasing HIV / AIDS sufferers, and 
increasing public unrest. Therefore the recommended steps to be taken by the government are:

a. Increase budget in the framework of development in the field of Religion;

b. Take strict actions in accordance with applicable laws towards producers, dealers and users and carry out effective, anticipatory and educative coordination steps with related parties and the community;

With the DPR, revise Law Number 22 Year 1997 concerning Narcotics and Law Number 5 Year 1997 concerning Psychotropic. ${ }^{26}$

Furthermore, the Government and DPR-RI then ratified and enacted Law Number 35 of 2009 concerning Narcotics. One of the fundamental changes to this law is to increase the status of BNN as a Non-Ministry Government Institution given the authority to investigate and investigate narcotics and narcotics precursors. In Law Number 35 of 2009 concerning Narcotics, it is regulated the threat of capital punishment as part of efforts to put deterrent effects on the perpetrators of circulation and illicit abuse of narcotics and narcotics precursors. for life which will ultimately weaken national security. ${ }^{27}$

In addition, related to the idea of inclusion of the threat of capital punishment threatened by producers and dealers in narcotics crimes, the Government of Indonesia has affirmed its opinion that the threat of capital punishment is necessary because it is considered as a crime of humanity which aims to destroy humanity slowly, because of all potential thinking and human mind is massively destroyed for personal and group interests. ${ }^{28}$ Then, the Government illustrates that narcotics crimes, human beings are made like living corpses that have no potential to build their civilizations and cultures anymore, but continue to behave to damage the order of life. ${ }^{29}$ Therefore, narcotics crimes will always be threatened with serious crimes including the threat of capital punishment. In addition to the views used by the Government, in this law it is intended to frighten people so that they do not commit criminal acts, both scaring people (generale preventive) and frightening certain people who have committed crimes so that they do not more criminal acts (special preventive). In addition, this law also aims to educate or improve people who have committed crimes in order to become people who have good character, so that they benefit society. ${ }^{30}$

The death penalty threat is seen as the right type of criminal sanction against the perpetrators of narcotics crimes with the qualifications of producers and distributors, because narcotics crime is a serious crime and the nature of criminal offenders who have a network to produce and distribute narcotics for business or economic interests only so that their actions can pose a great danger or have

\footnotetext{
26 Ketetapan MPR RI No.VI/MPR/2002 tentang Rekomendasi atas Laporan Pelaksanaan Putusan MPR oleh Presiden, DPA, DPR, BPK, dan MA.

27 Anggara dkk, (Tim Peniliti ICJR), 2017, Politik Kebijakan Hukuman Mati Di Indonesia Dari Masa Ke Masa, Institute For Criminal Justice Reform, hlm, 152

Putusan Mahkamah Konstitusi, Perkara Nomor 2/PUU-V/2007, hlm, 131.

Ibid

Wirjono Prodjodikoro, 1989, Asas-Asas Hukum Pidana Di Indonesia, Bandung, Eresco, hlm, 18.
} 
consequences that have a major effect on human life and the life of the country in the political, economic, social, cultural and national security fields. ${ }^{31}$

In the end the deterrent effect with very severe penalties, including the threat of capital punishment, was the target to achieve the goal of enacting Law No. 35 of 2009 concerning Narcotics in addition to providing narcotics for health needs and the development of science, also intended to reduce the quantity of perpetrators of abuse and circulation dark narcotics. Although it was realized that the enactment of this law the number of narcotics abuse and circulation by the perpetrators did not deter and could educate producers and distributors of the sentences imposed not comparable to their actions compared to the consequences suffered by victims. In other words, the target of regulating the death penalty in this law is not only for death row inmates, but also for potential perpetrators who have not been subject to a death sentence. Therefore, the threat of capital punishment is aimed at suppressing the high rate of criminality, which in turn the community becomes orderly, peaceful and safe.

In line with the basic ideas established by legislators and the views of legal experts in the determination of the norms of threat of capital punishment threatened by perpetrators with qualifications as producers and dealers as stated above, Muladi argues that the reason for the use of norms of the threat of capital punishment against perpetrators (producers and dealers) in narcotics crime, as follows: First, narcotics crimes, especially organized producers and distributors are crimes whose effects are "anthropocentric" (can destroy the younger generation) and tend to lead to organized transnational crime (transnational organized crimes ) which endangers national and international security. Even narcotics crime is a "predicate of crimes" (initial crime) against money laundering crimes whose results are used to develop other crimes such as terrorism; second, the character of narcotics crimes is a very serious crime, considering narcotics crimes as crimes that cause severe and extreme consequences including death; thirdly, narcotics crime is growing rapidly considering several diverse criminogen factors, so that it contains the potential danger of human security such as: high social mobility due to globalization, Indonesia has great democratic potential as a consumer of narcotics, geographical location as an archipelagic country vulnerable to infiltration, especially organized transnational crime. ${ }^{32}$

\section{Conclusion}

The basic idea of using the threat of capital punishment against perpetrators of "producers and dealers" regulated by Law Number 35 of 2009 concerning Narcotics as a policy to combat narcotics crime is based on several reasons, including: First, narcotics crimes committed by perpetrators of "producers and distributors "Organized and systematic patterns, because they are carried out with a very sophisticated modus operandi and have networks to circulate and trade for

\footnotetext{
31 Andi Hamzah dan Siti Rahayu, 1983, Suatu Tinjauan Ringkas Sistem Pemidanaan di Indonesia, Jakarta, Akademika Pressindo, hlm, 32.

32 Muladi, 2013, Bahan Kuliah HAM, Politik Hukum Dalam Pengaturan dan Pelaksanaan Pidana Mati di Indonesia, Khususnya Dalam Tindak Pidana Narkotika, hlm, 19-20.
} 
purely economic interests, so it is not easy to uncover and prove it. Second, the circulation and abuse of illicit drug trafficking by perpetrators of "producers and distributors" is a threat that sooner or later gives a serious impact because it destroys young generation, destroys the nation and the state that is not less powerful than criminal acts of terrorism and corruption, due to the fact that arising from narcotics abuse has caused victims of HIV / AIDS and hepatitis, even death among the very young generation. So that the Indonesian Government views that the actions of "producers and distributors" in producing and distributing narcotics are crimes against humanity, because their actions can destroy humanity slowly but surely. Third, the effects of narcotics abuse are very complex, such as moral, socioeconomic, physical, both individually and in society, so that in the end it will weaken national security. Fourth, efforts to put the deterrent effect on the perpetrators of "producers and distributors" of narcotics crimes and the public so as not to commit narcotics crimes, so that the individual legal interests of the people, and the legal interests of the state can be protected.

\section{References}

Syamsul Hidayat \& Hasan Asy"ari, 2013, “Kontroversi Penerapan Pidana Mati Terhadap Tindak Pidana Narkoba”, Dalam Jurnal IUS Kajian Hukum dan Keadilan, Vol I Nomor 3 Desember.

Wendra Hartanto, 2017, "Penegakan Hukum Terhadap Kejahatan Narkotika dan Obat-Obat Terlarang Dalam Era Perdagangan Bebas Internasional Yang Berdampak Pada Keamana dan Kedaulatan Negara" Jurnal Legislasi Indonesia, ISSN 0216-1338.

Santoso, 2013, Selaku Kepala Badan Narkotika Provinsi Maluku (BNP), Sebagaimana dikutip di Media Indonesia, Com, Indonesia "Surga Pengedar Narkoba Internasional” 26 Januari.

Achmad Rivai, 2014, Narkoba Di Balik Tembok Penjara, Yogyakarta, Aswaja Pressindo.

Hikmahanto Juwana, 2015, "Narkoba dan Hukuman Mati” Kompas, Senin 19 Januari

Wendra Hartanto, 2017, "Penegakan Hukum Terhadap Kejahatan Narkotika dan Obat-Obat Terlarang Dalam Era Perdagangan Bebas Internasional Yang Berdampak Pada Keamana dan Kedaulatan Negara" Jurnal Legislasi Indonesia, ISSN 0216-1338.

Santoso, 2013, Selaku Kepala Badan Narkotika Provinsi Maluku (BNP), Sebagaimana dikutip di Media Indonesia, Com, Indonesia "Surga Pengedar Narkoba Internasional” 26 Januari.

Achmad Rivai, 2014, Narkoba Di Balik Tembok Penjara, Yogyakarta, Aswaja Pressindo.

Hikmahanto Juwana, 2015, "Narkoba dan Hukuman Mati” Kompas, Senin 19 Januari.

Narkotika dalam arti medis diartikan sebagai zat atau obat yang digunakan untuk penekan rasa sakit dikulit, untuk pembedahan mata, hidung dan tenggorokan. Narkotika dalam arti psikiatri adalah zat atau obat yang mempengaruhi aspek 
kesehatan jiwa serta pengaruhnya terhadap fungsi-fungsi tubuh manusia. Narkotika dalam arti kesehatan jiwa adalah zat atau obat yang mempengaruhi suatu kondisi sehat, emosional, psikologis, dan hubungan interpersonal yang memuaskan, perilaku yang efektif dan kestabilan emosi. Sedangkan narkotika dalam arti psikososial adalah zat atau obat yang berpengaruh terhadap perkembangan emosi, motivasi dan perkembangan pribadi manusia, Diakses dari http://dedyarta Wordpress.com/2015/02/15/manfaat-narkotika dan psikotropika dalam bidang kesehatan, pada tanggal, 20 April 2018

Jhon M. Elthols dan Hasan Sadili, 1996, Kamus Inggris Indonesia, Jakarta, Gramedia Cet.XXIII.

Anton M. Moelyono, 1988, Kamus Besar Bahasa Indonesia, Jakarta, Balai Pustaka. Mardani, 2008, Bunga Rampai Hukum Aktual, Jakarta, Ghalia Indonesia.

Soedjono Dirdjosisworo, 1997, Patologi Sosial, Bandung, Alumni.

I Nyoman Nurjaya, 2005, "Penanggulangan Kejahatan Narkotika Dalam Perspektif Sosiologi Hukum", Malang, Legality; Jurnal Ilmiah Hukum, Fakultas Hukum Universitas Muhammadiyah.

Soedjono Dirjosisworo,1990, Hukum Narkotika Indonesia, Cet. 2, Bandung : Citra Aditya Bakti.

Undang-Undang RI No. 9 Tahun 1976 tentang Narkotika, LN RI Tahun 1976 No. 36, TLN RI No. 3086.

O. C. Kaligis dan Associates,2007, Narkoba dan Peradilannya di Indonesia Reformasi Hukum Pidana Melalui Perundangan dan Peradilan, Cet. 2, Bandung : Alumni.

Undang-Undang Nomor 22 Tahun 1997 tentang Narkotika, LN RI Tahun 1997 No. 67, TLN RI No. 3698

Ketetapan MPR RI No.VI/MPR/2002 tentang Rekomendasi atas Laporan Pelaksanaan Putusan MPR oleh Presiden, DPA, DPR, BPK, dan MA.

Anggara dkk, (Tim Peniliti ICJR), 2017, Politik Kebijakan Hukuman Mati Di Indonesia Dari Masa Ke Masa, Institute For Criminal Justice Reform.

Putusan Mahkamah Konstitusi, Perkara Nomor 2/PUU-V/2007.

Wirjono Prodjodikoro, 1989, Asas-Asas Hukum Pidana Di Indonesia, Bandung, Eresco.

Andi Hamzah dan Siti Rahayu, 1983, Suatu Tinjauan Ringkas Sistem Pemidanaan di Indonesia, Jakarta, Akademika Pressindo.

Muladi, 2013, Bahan Kuliah HAM, Politik Hukum Dalam Pengaturan dan Pelaksanaan Pidana Mati di Indonesia, Khususnya Dalam Tindak Pidana Narkotika. 